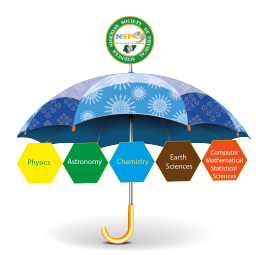

\title{
A review on Transforming plastic wastes into fuel
}

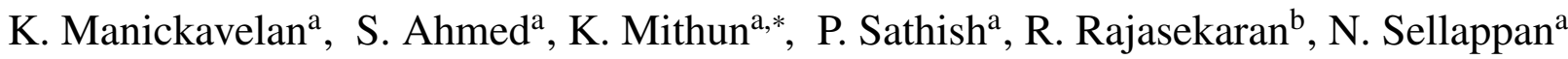 \\ ${ }^{a}$ Department of Engineering, Mechanical Engineering Section, University of Technology and Applied Sciences - Salalah, Salalah - Oman \\ ${ }^{b}$ Department of Engineering, Chemical Engineering Section, University of Technology and Applied Sciences - Salalah, Salalah - Oman
}

\begin{abstract}
The application of plastics in various sectors led to its increased production globally and this demand, in turn, caused an overflow of plastic waste in landfills, illegal dumping in the sea, and environmental pollution. To overcome this issue, several alternatives for managing plastic wastes have been developed and among them, reuse, recycling, and energy recovery methods are highly acknowledged methods. Nonetheless, recycling methods come with certain disadvantages like mixing and segregation of wastes, high labour costs associated with segregation and processing, byproduct disposal, and its usage. Researchers have shifted their focus to energy recovery systems because of these drawbacks. Extensive research in this area led to the development of converting waste plastics into liquid fuel through the process called pyrolysis. The pyrolysis process can thermally degrade plastics in the absence of oxygenproducing oil and monomers. The temperature has the most impact on the pyrolysis process and depending on the types of plastic wastes, the pyrolysis temperature varies between $300-800{ }^{\circ} \mathrm{C}$. The oil yield due to the variation in temperature varies between $45-95 \mathrm{wt} . \%$ and the calorific value of the oil has been observed to be in the range of $9679-11428.5 \mathrm{kCal} / \mathrm{kg}$, which is similar to the other commercial fuels. Also, the review indicates that it is possible to extract up to $84 \%$ of fuel from $1-\mathrm{kg}$ plastic at $360^{\circ} \mathrm{C}$. As a result, following refining/blending with conventional fuels, pyrolysis oil can be utilised as an alternate source of energy and transportation fuel. Apart from the temperature, the other influencing factors include, the reactor design and its size, pressure, heating rate, residence time and feedstock composition. The pyrolysis process was examined in terms of plastic types and primary process factors that impacted the end result, such as oil, gaseous, and char. Temperatures, reactor types, residence duration, pressure, catalysts, and other critical factors were examined in this work. Furthermore, the study examines technological problems and current advances.
\end{abstract}

\section{DOI:10.46481/jnsps.2022.364}

Keywords: Plastic wastes, Pyrolysis, Liquid fuel, Energy recovery, Recycling

Article History :

Received: 26 August 2021

Received in revised form: 16 January 2022

Accepted for publication: 5 February 2022

Published: 28 February 2022

(C)2022 Journal of the Nigerian Society of Physical Sciences. All rights reserved. Communicated by: W. A. Yahya

\section{Introduction}

Environmental problems and energy demand concerns have increased the global attention on recycling pathways. However, due to low recycling rates and the ever-expanding use of plastics has led to an exponential growth in the plastic waste generation. Thus, necessitating the development of new waste re-

${ }^{*}$ Corresponding author tel. no: $+968-96726334$

Email address: mv.kulkarni@sct.edu.om (K. Mithun ) fining technologies [1]. It is estimated that in the Sultanate of Oman alone, the percentage of plastics in the municipal solid waste (MSW) constitutes to be about $21 \%$ and by 2025 globally, the MSW is expected to rise by 2600 million tonnes per year. Plastics have high molecular weight ranging from thousands to millions. The excessive molecular size is the main cause for the non-biodegradable properties of plastics, making them persistent in soil environment for a long time. Plastics, fundamentally, are differentiated depending on their composi- 
tion, and normally reported based on their proximate analysis. Proximate analysis refers to a method for determining the chemical properties of the plastic compound based on four elements(1) moisture content, (2) fixed carbon, (3) volatile matter, and (4) ash content [2]. Particularly, the ash content and volatile matter influence oil production. High ash content favours gas and char formation and on the other hand high volatile matter favours liquid oil production [3]. It has been observed that high carbon ratio in the plastics favours producing products with high calorific value. The plastics listed in Table 1, have $\mathrm{C}$ ratio of $63.94 \%, 85.6 \%, 86.88 \%, 91.57 \%$ and $63.94 \%$ for High-density polyethylene (HDPE), Low-density polyethylene (LDPE), polypropylene (PP), Polystyrene (PS) and Polyethylene terephthalate (PET), respectively. Depending on the chemical structure, plastics have different thermal deposition temperatures. Usually for plastics listed in Table 1, the thermal decomposition starts at $350{ }^{\circ} \mathrm{C}$. However, if the desired output is other than liquid, then the operating temperature should be above 500 ${ }^{\circ} \mathrm{C}$, which helps in producing gas and char. Research indicates that plastics such as PET and PVC produced little liquid yield and some plastics like PVC will never be used in the pyrolysis process as they produce harmful gases with harmful substances as by-products [4].

Table 1: Proximate analysis of various plastic types

\begin{tabular}{llllll}
\hline \hline $\begin{array}{l}\text { Plastic } \\
\text { Type }\end{array}$ & $\begin{array}{l}\text { Moisture } \\
\text { (wt.\%) }\end{array}$ & $\begin{array}{l}\text { Fixed } \\
\text { carbon } \\
\text { (wt.\%) }\end{array}$ & $\begin{array}{l}\text { Volatile } \\
\text { matter } \\
\text { (wt.\%) }\end{array}$ & $\begin{array}{l}\text { Ash } \\
\text { content } \\
\text { (wt.\%) }\end{array}$ & Reference \\
\hline \hline HDPE & 0.00 & 0.00 & 99.92 & 0.08 & {$[5]$} \\
& 0.00 & 0.01 & 99.81 & 0.18 & {$[6]$} \\
LDPE & 0.3 & 0.00 & 99.70 & 0.00 & {$[7]$} \\
PP & 0.00 & 0.09 & 99.9 & 0.01 & {$[6]$} \\
PS & - & 0.1 & 99.9 & - & {$[8]$} \\
PET & 0.1 & 11.8 & 88.1 & - & {$[8]$} \\
Waste & 0.41 & 0.28 & 96.88 & 2.43 & {$[9]$} \\
Plastics & & & & & \\
\hline \hline
\end{tabular}

As shown in Table 2, plastics such as PET finds its use in household applications, in packaging industry, mineral water bottles, fruit juice containers and cans, etc. PET is also used in other applications such as printing sheets, magnetic tapes, X-ray films, etc. Since, most applications use PET, its pyrolysis has been observed to yield a liquid of $23.1 \mathrm{wt} . \%$ and gas of $76.9 \%[10,11]$. Acidic characteristics have also been observed in the pyrolysis oil that makes it difficult to directly blend with conventional fuels and/or use it directly in IC engines [12]. Another major contributor to the waste plastics generation from Table 2 is HDPE.

HDPE due to its lost cost, high strength properties, ease of forming and break resistance properties is used in several applications. Some applications are listed in Table 2. In a work by Ahmad et al. [6] a steel reactor was used to pyrolyze HDPE at temperatures ranging from 300 to $400^{\circ} \mathrm{C}$. Nitrogen was employed as the fluidising medium. At $300{ }^{\circ} \mathrm{C}, 33.05 \mathrm{wt} . \%$ of solid residue was obtained and at $350^{\circ} \mathrm{C}$, a total of $80.88 \mathrm{wt} . \%$ liquid was collected. Kumar and Singh [13] used a semibatch reactor to conduct a thermal pyrolysis investigation of HDPE at a higher temperature of $400-550^{\circ} \mathrm{C}$. They noted that the thermal decomposition of waste HDPE can be enhanced to produce useful products by using appropriate catalysts. Catalysts are observed to increase the chemical reaction and help in distributing hydrocarbons to obtain pyrolysis liquid that has properties nearly similar to conventional fuels such as diesel and petrol. The most typical catalysts that were employed in this process included zeolite, alumina, and zirconium oxide. Also, the impact of different catalysts on pyrolysis of HDPE is being explored by a variety of researchers. However, the details about the use of the catalyst in the pyrolysis process will be discussed in detail in the sections to follow.

Low-density polyethylene (LDPE) plastics due to their excellent water resistance are used in a wide variety of applications. Bagri and Williams [14] and Marcilla et al. [15] used LDPE as a raw material in the pyrolysis processes for obtaining the liquid fuel oil, a fixed-bed reactor at $500^{\circ} \mathrm{C}$ with a heating rate of $10^{\circ} \mathrm{C} / \mathrm{min}$ and a batch reactor at $550^{\circ} \mathrm{C}$ with a heating rate of $5^{\circ} \mathrm{C} / \mathrm{min}$ and liquid yields of 95 and 93.1 percent, were reported by them, respectively [11].

The raw materials derived from waste plastics will play a decisive role in the transformation of the petrochemical industry by 2030 and with technological development, one-third of the plastics entering the global market will be manufactured from recycled plastics [16]. However, recycling of plastics waste must meet several obstacles and problems, along with fiscal unfeasibility. There arises a slew of technological hurdles to overcome, when dealing with increasingly difficult to melt plastic items, such as multi-layer materials or polymers that include many toxic compounds, such as brominated flame retardants, raw material availability, raw material selection, pre-treatment, choice of reactor, etc., [17].

However, before discussing the technical challenges, it is important to discuss various plastic recycling methods. Figure 1 lists the four main plastic recycling methods (primary, secondary, tertiary and quaternary).

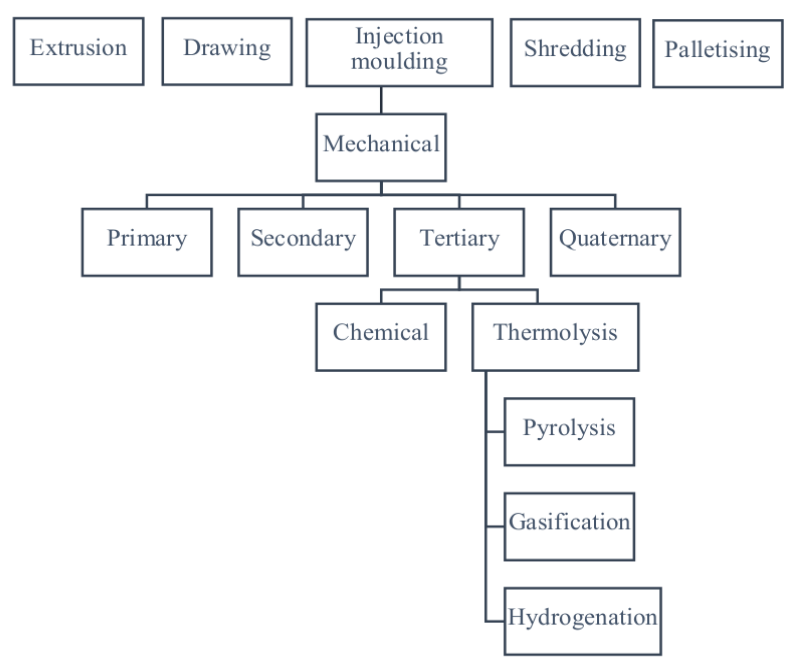

Figure 1: Various approaches for recycling of plastic wastes [19] 
Table 2: Municipal Waste Sources, major plastic types from MSWs and pyrolysis products [18]

\begin{tabular}{|c|c|c|c|}
\hline Source & Types of Solid Waste & $\begin{array}{l}\text { Major Plastic Types } \\
\text { from MSWs }\end{array}$ & $\begin{array}{l}\text { Pyrolysis Products from } \\
\text { waste plastics from MSWs }\end{array}$ \\
\hline Residential & $\begin{array}{l}\text { Food wastes, paper, cardboard, } \\
\text { plastics, textiles, leather, gar- } \\
\text { den wastes, wood, glass, met- } \\
\text { als, ashes, special wastes (e.g., } \\
\text { bulky items, consumer elec- } \\
\text { tronics, white goods, batteries, } \\
\text { oil, tyres), detergent bottles and } \\
\text { household hazardous wastes. }\end{array}$ & $\begin{array}{l}\text { PE, PP, PS, PET, } \\
\text { HDPE }\end{array}$ & $\begin{array}{l}\text { Waxes, paraffins, olefins, } \\
\text { Benzoic acid, vinyl } \\
\text { terephthalate }\end{array}$ \\
\hline $\begin{array}{l}\text { Industrial and } \\
\text { automotive }\end{array}$ & $\begin{array}{l}\text { Housekeeping wastes, pack- } \\
\text { aging products, food wastes, } \\
\text { construction hazardous wastes, } \\
\text { ashes, plastics } \mathcal{E} \text { polymers, } \\
\text { special wastes. }\end{array}$ & PUR, PMMA, PA6, & $\begin{array}{l}\text { Waxes, paraffins, olefins, } \\
\text { Benzene, methane, } \\
\text { ethylene, } \mathrm{NH}_{3}, \mathrm{HCN} \text {, } \\
\text { Caprolactam }\end{array}$ \\
\hline $\begin{array}{l}\text { Construction } \\
\& \text { Demolition }\end{array}$ & $\begin{array}{l}\text { Wood, steel, concrete, dirt, plas- } \\
\text { tic doors, etc. }\end{array}$ & PUR, PVC & $\begin{array}{l}\text { Benzene, methane, } \\
\text { ethylene, } \mathrm{NH}_{3}, \mathrm{HCN}, \mathrm{HCl} \\
\left(<300^{\circ} \mathrm{C}\right) .\end{array}$ \\
\hline $\begin{array}{l}\text { Municipal } \\
\text { Services }\end{array}$ & $\begin{array}{l}\text { Street sweepings; landscape and } \\
\text { tree trimmings; general wastes } \\
\text { from parks, beaches, and other } \\
\text { recreational areas; Sludge Pro- } \\
\text { cess, single use plastic bags } \\
\text { (manufacturing, etc.) }\end{array}$ & PE, PP & Waxes, paraffins, olefins. \\
\hline Agriculture & $\begin{array}{l}\text { Spoiled food wastes, agricul- } \\
\text { tural wastes, hazardous wastes } \\
\text { (e.g., pesticides), plastics used } \\
\text { for storing pesticides, etc }\end{array}$ & PE, HDPE & Waxes, paraffins, olefins \\
\hline
\end{tabular}

$\mathrm{PE}=$ Polyethylene, $\mathrm{PP}=$ Polypropylene, $\mathrm{PS}=$ Polystyrene, $\mathrm{PA}-6=$ =Polyamide 6, PMMA=Polymethyl methacrylate, $\mathrm{PET}=$ Polyethylene terephthalate, $\mathrm{PUR}=$ Polyurethane resin, $\mathrm{PVC}=$ Polyvinyl Chloride, $\mathrm{HCl}=\mathrm{Hydrochloride}$

\section{(a) Primary recycling}

In this process, the uncontaminated single-use plastic after sorting out or recovered from plastic wastes having properties and characteristics close to virgin materials is recycled [20, 21]. This method needs a better sorting technique as plastics recovered from MSW may not be suitable and useful for recycling [19]. To obtain better materials than the original products, many times clean scarp is added during the recycling process. Often techniques such as injection moulding, blow moulding and other mechanical recycling techniques are used in primary recycling technique [21] and is also one of the simplest methods for recycling plastics. But the process also carries a certain disadvantage like it puts a limit on the number of cycles that waste plastics can be recycled [22].

\section{(b) Secondary recycling}

Secondary recycling (SR) refers to the transformation of scrapped thermoplastics into products that are less demanding than compared to the original products. But looking at both primary and secondary techniques, these are wellestablished techniques and are widely applied in the transformation of plastic wastes into useful products [23]. As an example for SR, polyolefins are used in the preparation of flooring tiles [19]. SR is also referred to as mechanical recycling [22] and involves cutting, separation of contaminants, and segregation followed by processing, milling, washing, adding pigments and additives for obtaining the granulated form. These are further used for preparing useful products through techniques such as injection moulding, blow moulding, screw extrusion and so on.

(c) Tertiary recycling

In this method, plastics are completely broken down into chemical component materials [24] that help in the production of raw materials used for making plastic components, and thus giving an opportunity for the recyclers to employ this method for recycling giving preference over the primary and secondary techniques [19]. For example, for tertiary recycling, glycolysis of PET into diols and dimethyl terephthalate can then be used to make virgin PET [20]. Tertiary methods can be sub-classified into chemical and thermolysis methods. Thermolysis is further classified into pyrolysis, gasification and hydrogenation as seen from Figure 1. Among these, pyrolysis process is an area where most of the research on recycling plastic wastes has taken 
place.

\section{(d) Quaternary recycling}

In this process, the energy from waste plastics is recovered by burning or firing them. Fuel obtained from scrapped tyres, generally known as Tyre-derived fuel (TDF) is an example of the quaternary recycling method.

\section{Technical Challenges}

Pyrolysis oil as observed from various literature is made up of various hydrocarbons, many of which are partially oxygenated with the presence of water, ash, and charcoal. The composition of the oil is much influenced by the various process parameters and must overcome the challenges posed by these process parameters. The toxicity of oil and its unstableness in air possess furthermore challenges for having to be used directly into the engine. Although, the main goal of the pyrolysis of plastic waste oil is to use it in engines directly, but the existing technology does not allow it to do so. The presence of charcoal, water and ash particles needs to be removed before blending it along with conventional fuels and or to replace the existing conventional fuels, raw material availability, viscosity, combustion behaviour, wax formation, the choice of reactors, etc., are other challenges that are discussed below.

\subsection{Raw material availability}

Even with various approaches, attempts to popularise and make the plastic recycling methods economical have failed in the past due to the non-continuous / non-steady supply of consistent quality raw materials [25]. According to Ragaert et al. [26], the economics of plastic recycling depends on the quantity of the raw material available at any given point in time. Previously, China was the largest importer of plastic wastes, off late it has banned all imports and thus large volume of waste plastics needs to be treated locally [25]. But the ban by China has opened the door of opportunities in waste management sector such as, awareness of reuse and recycling wastes, preserving the ecosystem, employment generation, alternate fuels, alternate materials in construction sector, etc. However, to tap the opportunities, it is necessary to have a steady flow of consistent quality of raw materials, with bans and strict laws by several countries in place supply of raw materials may not be a problem in the future.

\subsection{Feedstock selection}

The plastic wastes collected from various sources are heterogeneous. The types of polymers used, vary for different applications. The plastic wastes, if segregated at the source of generation could solve most of the problems associated with raw material availability and selection. But for this, awareness among the public is essential.

Polyolefin occupies a major share of plastic items, owing to their chemistry and synergistic reasons, they are considered an ideal choice as a feed for pyrolysis process. Also, most applications use PET and PVC plastics, which contributes largely towards waste plastics generation, yet they are not an ideal choice for the pyrolysis process. Upon thermal degradation of PET and PVC, the latter has corroded the equipment due to the release of the chlorine containing compounds and renders the oil halogenated. Alternatively, PET tends to decompose into phthalic acids deteriorating the oil quality [25].

\subsection{Pre-treatment}

Many plastics come with different forms and sizes that make it mandatory to uniformly size them before they are used as a raw material for various other steps. Thus, this step adds an extra cost for the entire process [25].

\subsection{Material feeding}

One of the most difficult tasks in plastic recycling is the material feeding job, as non-uniform size and shape of waste plastics pose a direct challenge during certain recycling processes. Some recycling methods include screw feeders for processing but plastic wastes when in the form of sheet, wrap around the screw feeders and form a lump/melt of semi solid plastic and make it difficult to continue with the feeding [25].

\subsection{Wax formation}

One of the principal results of the pyrolysis of plastics, particularly polyolefins, is wax. When wax is the primary result of plastic pyrolysis, the recovery system must be built specifically for waxes. When using standard condensing systems, the wax tends to condense on the condenser walls, making it harder to reclaim the material during the process.

\subsection{Choice of reactor}

Although there are many types of reactors in use, only four important types of reactors have been reviewed and compared (refer Table 3) in this section.

\subsubsection{Fluidized-bed reactor (FB reactor)}

In this type of reactor (Figure 2a), due to the presence of solid particles and the fluidisation gas (flowing continuously) on the bed, makes the bed to be in a fluid-like state. The desired reaction occurs when the raw material is fed into the reactor [27]. The FB reactor are known for their ease of operation and less maintenance cost. They are considered the best for continuous operation and provide a degree of freedom when choosing different fluidisation agents and offers excellent heat and mass transfer capabilities. But when the operating conditions are poorly selected possibility of bed defluidization can occur and plastics tend to stick to the surface of the bed particles, thus making the operation a little complicated. Even some times feeding can also be difficult due to particle size restriction [28].

\subsubsection{Fluid Catalytic cracking reactor (FCC reactor)}

A chemical process (Figure $2 b$ ) used to produce gasoline and distillate fuels with the help of catalyst [29]. It is one of the widely used methods in conventional refinery [28]. The catalyst in the solid form is made fluid when the hot vapour and fluid are fed into the FCC. Now, since the catalyst is in the liquid form 
it can easily move around between reactor and regenerator vessels in the FCC reactor. Thus, the catalysts and heat are used to break down the larger gas molecules into molecules of petrol, butane, distillates etc., [29]. In this process, during the cracking process, carbon gets deposited on the catalyst and thus will be referred to as catalyst coke. The main disadvantage of carbon deposition is that the ability of the catalyst to crack the oil gets reduced. In the process, flue gas is produced as a cause of regeneration, passes through the environmental control equipment, and finally discharged into the atmosphere.

\subsubsection{Continuous Stirred Tank Reactor (CSTR)}

In this type of reactor, the product(s) of the reaction concomitantly moves out of the vessel when the reactants, solvents and reagents enter the reactor. Thus making the reactor an important tool in the processing of the chemicals continuously and hence the name CSTR. The advantages of this reactor are effectively mixing, easy accessibility to the interior of the reactor, the cost of reactor construction, and the capability to work under steady-state with uniform properties [30]. Another characteristic feature of CSTR is that the material's composition inside the reactor is the same as the output composition, which is a function of the reaction rate and residence time.

\subsubsection{Screw Reactor}

Screw reactors contains a tubular reactor and a screw conveyor. This rector can be used to pyrolyze thermoset plastics, which are otherwise considered as a difficult to treat plastics. The reactor can effectively and efficiently remove chlorine in the case of mixed plastic waste. Also, by varying the screw length and screw speed, it is possible to vary the residence time. Excellent heat transfer and selective zone heating are the added features of screw reactors.

\section{What is Pyrolysis?}

The thermal degradation of long-chain polymer molecules into smaller and simpler ones is known as pyrolysis. In the absence of oxygen, the technique needs extremely high temperatures for a short duration. The three main products produced by pyrolysis are oil, gas, and char, which are important in industries such as manufacturing and refining.

Many researchers selected pyrolysis because it can create a large volume of liquid oil (up to $80 \mathrm{wt} . \%$ ) at a modest temperature of roughly $500{ }^{\circ} \mathrm{C}$ [4]. Furthermore, pyrolysis is extremely adaptable since process parameters may be tweaked to enhance product yield based on preferences. The liquid oil generated may be utilised in various applications, including furnaces, boilers, turbines, and diesel engines, without any further treatment or upgrade [5]. Biomass pyrolysis oil has received a lot of interest as a more environmentally friendly fuel since it helps lower $\mathrm{CO}_{2}$ levels in the atmosphere. In contrast to recycling, the process handling is significantly easier and more flexible because it does not require a thorough sorting method, making it less labour intensive [6].
Table 3: Reactor comparison for plastic thermolysis. Modified from [49]

\begin{tabular}{|c|c|c|c|c|}
\hline & \multicolumn{4}{|c|}{ Reactor type } \\
\hline & $\begin{array}{l}\text { Fixed } \\
\text { Bed }\end{array}$ & $\begin{array}{l}\text { Vacuum } \\
\text { pyrolysis }\end{array}$ & $\mathrm{CSTR}^{\#}$ & $\begin{array}{l}\text { Screw } \\
\text { type }\end{array}$ \\
\hline $\begin{array}{l}\text { Temperature } \\
\text { control }\end{array}$ & $\mathrm{P}$ & $\bar{S}$ & $\mathrm{G}$ & $\mathrm{P}$ \\
\hline Heat transfer & $\mathrm{P}$ & $\mathrm{S}$ & $\mathrm{G}$ & $\mathrm{P}$ \\
\hline $\begin{array}{l}\text { Particle size } \\
\text { flexibility }\end{array}$ & $S$ & G & $\mathrm{S}$ & $\mathrm{S}$ \\
\hline $\begin{array}{l}\text { residence } \\
\text { time flexibil- } \\
\text { ity }\end{array}$ & $\bar{G}$ & $\bar{G}$ & $\bar{G}$ & $\mathrm{G}$ \\
\hline $\begin{array}{l}\text { process flexi- } \\
\text { bility }\end{array}$ & $P$ & $\mathrm{~S}$ & $\mathrm{~S}$ & $\mathrm{~S}$ \\
\hline $\begin{array}{l}\text { Thermal } \\
\text { mode opera- } \\
\text { tion }\end{array}$ & $\mathrm{S}$ & G & $\mathrm{S}$ & $\mathrm{G}$ \\
\hline $\begin{array}{l}\text { Catalytic } \\
\text { mode opera- } \\
\text { tion }\end{array}$ & $S$ & $S$ & na & $\mathrm{S}$ \\
\hline $\begin{array}{l}\text { Value of ob- } \\
\text { tained prod- } \\
\text { uct }\end{array}$ & G & $S$ & $\mathrm{G}$ & $\mathrm{S}$ \\
\hline $\begin{array}{l}\text { Scale-up } \\
\text { flexibility }\end{array}$ & $\mathrm{P}$ & $S$ & $\mathrm{G}$ & $\mathrm{S}$ \\
\hline $\begin{array}{l}\text { Economic } \\
\text { feasibility }\end{array}$ & $\mathrm{S}$ & S & G & $\mathrm{S}$ \\
\hline
\end{tabular}

Pyrolysis produces a combination of molecules in the form of liquid or wax as the major products, depending on the process circumstances [10]. The liquid or wax that is produced can subsequently be utilised as a feedstock for refining chemicals or fuels $[11,12]$. The primary pyrolysis products from various polymers are listed in Table 2 . Some resins, such as PS, PA, and PMMA, have high monomer yields, which is of particular importance. However, municipalities collected plastic garbage is frequently a combination of different polymers, resulting in a mixture of these goods.

\subsection{Types of Pyrolysis}

Pyrolysis is mainly categorised into three types viz., slow, intermediate, and fast as shown in Figure 3. Literature indicate that fast pyrolysis liquid oil obtained can be used in internal combustion engines [11].

Slow pyrolysis includes the gradual heating of waste plastics at over $500^{\circ} \mathrm{C}$ in the absence of oxygen. Carbonisation is another name for slow pyrolysis. Solid charcoal is a major result of slow pyrolysis [11], where fast pyrolysis involves a great and rapid heating in the absence of air, often in the temperature range of $450-650{ }^{\circ} \mathrm{C}$ produces products such as char, gas, and organic vapours. In most cases, $60-75$ wt.\% of the feedstock is converted to oil [31]. Intermediate pyrolysis, also known as 


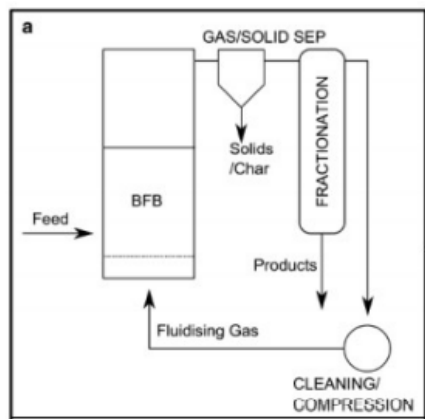

(a) Fluidized bed

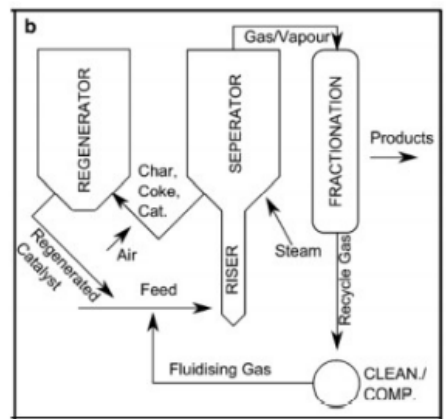

(b) Fluid catalyatic cracking

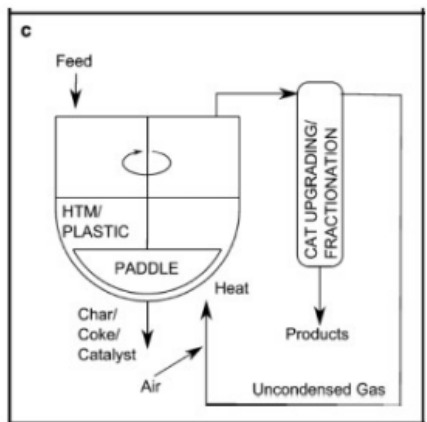

(c) CSTR reactor

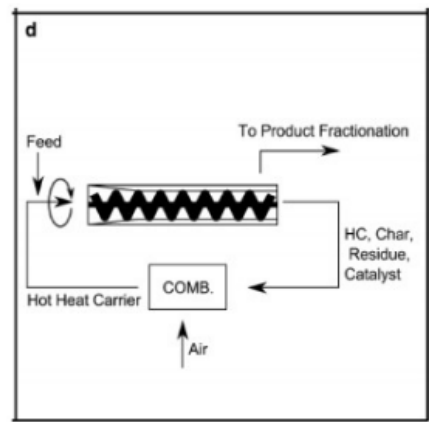

(d) Screw reactor

Figure 2: Common reactors for plastic pyrolysis [28]

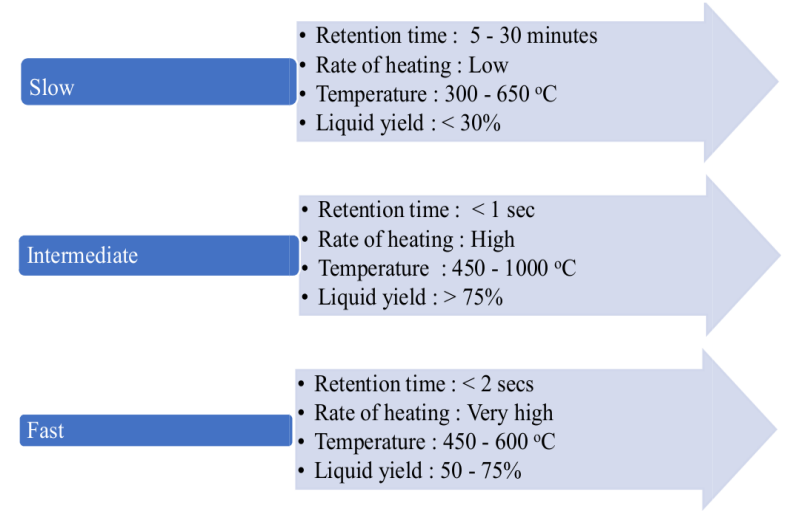

Figure 3: Pyrolysis types and their operating parameters and product yields [11]

flash pyrolysis is a rapid heating process with a short residence time of less than 1 second. Around $75 \%$ of the feedstock can be converted into liquid yield using the flash pyrolysis process.

\subsection{Process Parameters influence on product yield}

In pyrolysis, parameters are crucial for optimising product yield and composition.Temperature, reactor type, pressure, residence time, etc., are factors that impact the liquid oil output during pyrolysis. Table 4 lists the comparison of various parameters with the different reactors. Among the parameters, the temperature controls the cracking reaction; thus, treated as the most important operational parameter in pyrolysis.Depending on the plastic type and its chemical structure, the degradation temperature varies. Usually, the type of product required from pyrolysis is known to be influenced by temperature.For instance, if the char and gaseous product is desired, temperature more than 500 ${ }^{\circ} \mathrm{C}$ is preferred and in case liquid (oil) is desired then the temperature in the range of $300-500{ }^{\circ} \mathrm{C}$ is preferred for plastics such as PET, PP, PS, etc. [2].

Besides temperature, reactors play an important role in improving the reaction efficiency and producing the desired end product and a few of the important reactors have already been discussed in the previous sections.Pressure and residence time are temperature-dependent factors that influence the pyrolysis process, especially at lower temperatures.Higher pressure increases the gaseous yield, yet most research is conducted at atmospheric pressure only. The effect of residence time becomes less apparent at higher temperatures.However, at temperature below $450{ }^{\circ} \mathrm{C}$ both pressure and residence time factors should be given much importance.

Catalysts are known to and have been tried to enhance the reaction efficiency and improve the hydrocarbon distribution in the pyrolysis process. The use of catalyst helps in obtaining the pyrolysis oil that has characteristics close to regular fuels such as diesel and petrol.The catalyst such as Zeolite was used in the pyrolysis by Miskolezi et al. [32]. It was proved that Zeolite helps in reducing impurities and enhances the efficiency of liquid yield.A study on the use of bentonite clay in the form of pelletized catalyst for the pyrolysis of plastic wastes such as PS, PP, LDPE, and HDPE was taken up by Supattra Budsaereechai et al. [33]; observations revealed that the liquid oil produced, had a higher calorific value than compared with the experiments that used catalyst.Maximum production of gas was reported in the case of pyrolysis of PP with an alumina-loaded catalyst by Obali et al. [34]. A pyrolysis comparison study of PP and PS using thermally activated natural zeolite catalyst and acid $(\mathrm{HCl})$ activated natural zeolite catalyst indicated more gas formation using the latter catalyst by Syamsiro et al. [35]. A summary of the effect of process parameters is shown in Table 4.

\subsection{Liquid fuel properties of plastic pyrolysis oil}

The fuel properties of waste LDPE, HDPE, PP and mixed plastics using the pyrolysis process are summarised in Table 5.The experimental calorific value of waste plastics discussed in Table 4 are close to the commercial standard values as depicted in Table 5.

However, work by Onwudili et al. [40] noted that PS had a lower calorific value than polyolefin plastics because of the presence of an aromatic ring in the chemical structure, which had a lower combustion energy than aliphatic hydrocarbons.Also, Sharuddin et al. [2] in their research review paper noted that, because of the presence of benzoic acid in PET and chlorine compound in PVC, reduced the fuel quality, PET and $\mathrm{PVC}$ had the lowest calorific value.The viscosity measurement 
Table 4: Effect of process parameters on plastic waste pyrolysis

\begin{tabular}{|l|l|}
\hline $\begin{array}{l}\text { Process parame- } \\
\text { ters }\end{array}$ & Findings \\
\hline $\begin{array}{l}\text { Effect of heating } \\
\text { rate and operating } \\
\text { temperature }\end{array}$ & $\begin{array}{l}\text { Higher heating rates and operat- } \\
\text { ing temperature causes breaking of } \\
\text { bond and thus helps in the produc- } \\
\text { tion of smaller molecules [36]. Rise } \\
\text { in temperature causes easier conver- } \\
\text { sion by reducing the aliphatic con- } \\
\text { tent [37]. }\end{array}$ \\
\hline Effect of pressure & $\begin{array}{l}\text { Coke is formed as a result of con- } \\
\text { densation of reactive fragments at } \\
\text { lower pressure [36]. During thermal } \\
\text { degradation of PE plastics, the reac- } \\
\text { tion pressure was seen to have a sig- } \\
\text { nificant impact on the distribution } \\
\text { of degradation products, providing a } \\
\text { mechanism to regulate product dis- } \\
\text { tribution [38]. }\end{array}$ \\
\hline Residence time & $\begin{array}{l}\text { Usually, residence time increases } \\
\text { the conversion. Secondary conver- } \\
\text { sion of primary products happens } \\
\text { with longer residence time thereby } \\
\text { producing more tar, thermally stable } \\
\text { products, and coke [37]. }\end{array}$ \\
\hline $\begin{array}{l}\text { Presence of gases } \\
\text { such as } \mathrm{N}_{2}, \text { Ar, } \mathrm{O}_{2} \\
\text { or } \mathrm{H}_{2} .\end{array}$ & $\begin{array}{l}\text { Presence of gases have an influence } \\
\text { over the kinetics, equilibrium, and } \\
\text { mechanism. The gases also help in } \\
\text { heat generation and product dilution } \\
{[36,37] .}\end{array}$ \\
\hline $\begin{array}{l}\text { To fast-track the chemical reaction, } \\
\text { catalysts are employed. The most } \\
\text { widely utilized catalysts in the py- } \\
\text { rolysis process are Zeolite, silica } \\
\left.\text { (SiO }{ }_{2}\right), \text { calcium oxide }(\text { CaO), and } \\
\text { alumina }\left(A l_{2} \mathrm{O}_{3} \text { ). These catalysts }\right. \\
\text { help to shorten the reaction time and } \\
\text { enhances the reaction rate [39]. }\end{array}$ \\
\hline
\end{tabular}

of waste plastics was also made, as it is an important property, and is defined as the fluid resistance to flow $[2,40]$.The viscosity values determined at different temperatures can be noted from Table 5.

Except for LDPE and mixed plastics from Table 5 and PS [2], the viscosity of HDPE and PP were close to the viscosity of commercial standard diesel value from Table 6. Pour point refers to the temperature at which a fluid ceases to flow owing to an increase in viscosity and it is also an important quality specification for diesel fuels [41].Generally, greater aromatic content and lesser wax (paraffin) is observed in fuels with lower PoP $[2,41]$.HDPE, mixed plastics, PP from Table 5 and PS [2] have lower PoP than commercial diesel, which has a PoP of $6{ }^{\circ} \mathrm{C}$ as shown in Table 5.The values obtained indicate that pyrolysis oil is rich with aromatic content and possesses low calorific value compared to commercial diesel and petrol.One of the important properties to avoid or prevent fire accidents during storage of fuel is its flash point (FP).The FP is the lowest temperature at which a solvent may ignite a flammable combination in air near the liquid's surface.The lower the flash point of a liquid solvent, the easier it is to ignite it [42]. From Table 5 it is observed that waste plastics possess low FP temperature compared to commercial fuels and it is essential to exercise precaution while handling and storing the pyrolysis oil.

\subsection{By-products of the plastic pyrolysis}

Along with oil, as discussed previously, the pyrolysis process also produces char and gas as by-products. Researchers have noted that process parameters such as heating rate, the presence of gases such as $\mathrm{N}_{2}, \mathrm{Ar}, \mathrm{O}_{2}$ or $\mathrm{H}_{2}$, pressure, residence time, and temperature play a greater role in the by-product generation. Table 7 lists the by-products of the pyrolysis process.

Char as a by-product is formed due to (1) slow heating at a low temperature (2) longer residence time. This by-product has certain advantages like being used as an adsorbent in water treatment to remove heavy metals through an upgrading treatment [2], its low sulphur content makes it usable as a fuel as the calorific value of char is about $18.8 \mathrm{MJ} / \mathrm{kg}$, and can be used in laying of roads and building materials [51], char-based sensors and supercapacitors $[52,53,54,55]$. The pyrolysis of PVC and PET compared to polyolefins and PS produced a large amount of gases. The composition of the gas mainly depends on the type of material used in the pyrolysis process. For instance, plastics such as HDPE, PET, PVC produced gases such as $\mathrm{H}_{2}$, $\mathrm{CH}_{4}, \mathrm{C}_{4} \mathrm{H}_{10}, \mathrm{C}_{2} \mathrm{H}_{6}, \mathrm{C}_{3} \mathrm{H}_{8}$, etc. Interestingly, PET produced additional gases such as $\mathrm{CO}_{2}$ and $\mathrm{CO}$, while $\mathrm{HCl}$ was produced by PVC. The gases produced using the pyrolysis process also has a good calorific value (PE and PP have a CV of 42 and $50 \mathrm{MJ} / \mathrm{kg}$, respectively) [44]. For maximising the gas production in the pyrolysis process, a longer residence time and higher temperatures are required. But these come with a price, that's lower oil production [56].

\section{Recent Developments in plastic waste pyrolysis}

Most of the recent works on waste plastic pyrolysis has taken place in the areas related to the use of renewable energy, biorefineries and bimetallic catalysts. The details of which have been discussed below.

Pyrolysis process can be treated as one of the sources of renewable energy, but the process has some drawbacks like it needs an external source of energy to heat the reactors and thus pollution associated with it has also to be taken care of. To deal with these issues, researchers have focussed their attention on the use of solar energy for heating the reactors.Aklilu et al. [62] focussed on design and testing a solar-assisted pyrolysis process for the production of liquid fuel from HDPE plastics. The results of the study indicated that $1360 \mathrm{kWh} / \mathrm{m}^{2}$ of solar energy was required to produce 14.2 litres of liquid fuel from HDPE waste.Further, they noted that the heating value of the produced liquid fuel was $41.8 \mathrm{MJ} / \mathrm{kg}$.Chaouki Ghenai et al. [63] designed a grid-tied solar PV power system to meet the energy demand 
Table 5: Characteristics of pyrolysis oil

\begin{tabular}{|c|c|c|c|c|c|c|c|}
\hline \multirow{2}{*}{$\begin{array}{l}\text { Waste plastic } \\
\text { Type }\end{array}$} & \multirow[t]{2}{*}{ Type of Reactor } & \multicolumn{5}{|c|}{ Characteristics of pyrolysis oil } & \multirow[t]{2}{*}{ Reference } \\
\hline & & $\mathrm{V}(\mathrm{cSt})$ & $\rho, g / c c$ & $\mathrm{FP},{ }^{\circ} \mathrm{C}$ & $\mathrm{PoP},{ }^{\circ} \mathrm{C}$ & $\begin{array}{l}\mathrm{CV}, \\
\mathrm{kcal} / \mathrm{kg}\end{array}$ & \\
\hline \multirow{9}{*}{ HDPE } & \multirow{2}{*}{$\begin{array}{l}\text { Fixed bed } \\
\text { pyrolysis } \\
\text { batch } \\
\text { reactor }\end{array}$} & $1.980^{a}$ & $0.7477^{a}$ & 14 & $<-15$ & 9829.35 & \multirow{2}{*}{ [43] } \\
\hline & & $\begin{array}{l}\text { ASTM } \\
\text { D445 }\end{array}$ & IP $131 / 57$ & $\begin{array}{l}\text { ASTM } \\
\text { D93 }\end{array}$ & $\begin{array}{l}\text { ASTM } \\
\text { D97 }\end{array}$ & $\begin{array}{l}\text { Bomb } \\
\text { Calorime- } \\
\text { ter } 12 / 58\end{array}$ & \\
\hline & \multirow{3}{*}{ Semi-batch } & $3.3^{a}$ & $0.8006^{c}$ & 10 & 18 & $10,573.71$ & \multirow{3}{*}{ [5] } \\
\hline & & IS: 1448 & IS: 1448 & IS: 1448 & IS: 1448 & IS:1448 & \\
\hline & & $\mathrm{P}: 25$ & P:16 & $\mathrm{P}: 20$ & P:10 & P:6 & \\
\hline & \multirow{2}{*}{$\begin{array}{l}\text { Pilot scale two } \\
\text { stage reactor } \\
\text { using batch } \\
\text { system }\end{array}$} & $2.319^{a}$ & $0.7991^{c}$ & $<10$ & 24 & 10234.226 & \multirow{2}{*}{ [44] } \\
\hline & & $\begin{array}{l}\text { ASTM D } \\
445\end{array}$ & $\begin{array}{l}\text { ASTM } \\
\text { D1298 }\end{array}$ & $\begin{array}{l}\text { ASTM } \\
\text { D93 }\end{array}$ & $\begin{array}{l}\text { ASTM D } \\
97\end{array}$ & $\begin{array}{l}\text { ASTM } \\
\text { D240 }\end{array}$ & \\
\hline & \multirow{2}{*}{$\begin{array}{l}\text { Horizontal } \\
\text { Steel }\end{array}$} & $5.08^{a}$ & $0.89^{c}$ & 48 & -5 & 9679.732 & \multirow{2}{*}[2,6]{} \\
\hline & & IP $71 / 87$ & IP160/87 & $\begin{array}{l}\text { IP } \\
34 / 85\end{array}$ & IP $15 / 67$ & IP $12 / 80$ & \\
\hline \multirow{4}{*}{ LDPE } & \multirow{2}{*}{ Batch reactor } & $1.24^{a}$ & $0.773^{c}$ & - & - & - & \multirow{2}{*}{ [45] } \\
\hline & & $\begin{array}{l}\text { ASTM } \\
\text { D445 }\end{array}$ & $\begin{array}{l}\text { ASTM } \\
\text { D1298 }\end{array}$ & - & - & - & \\
\hline & \multirow{2}{*}{ Tube reactor } & $1.117^{a}$ & - & 22 & - & 11089.87 & \multirow{2}{*}{ [46] } \\
\hline & & - & - & - & - & - & \\
\hline \multirow{2}{*}{$\begin{array}{l}\text { Mixed } \\
\text { plastic bags } \\
\text { (PE, PP) }\end{array}$} & \multirow{2}{*}{ Self-designed } & $0.8^{a}$ & $0.735^{a}$ & 29 & - & 11428.5 & \multirow{2}{*}{ [47] } \\
\hline & & - & - & - & - & - & \\
\hline \multirow{4}{*}{ Mixed Plastics } & \multirow{2}{*}{ Self-designed } & $2.8^{b}$ & $0.76^{a}$ & 35 & - & 10809.27 & \multirow{2}{*}{ [48] } \\
\hline & & - & - & - & - & - & \\
\hline & \multirow{2}{*}{ Self-designed } & - & $0.7365^{c}$ & 22 & $<-20$ & 11262 & \multirow{2}{*}[37,49]{} \\
\hline & & - & - & - & - & - & \\
\hline \multirow{2}{*}{ Polyolefin } & \multirow{2}{*}{ Self-designed } & - & $0.68^{a}$ & 29 & - & - & \multirow[t]{2}{*}{ [50] } \\
\hline & & - & - & - & - & - & \\
\hline \multirow{2}{*}{ PP } & \multirow{2}{*}{ Horizontal Steel } & $4.09^{a}$ & $0.86^{c}$ & 30 & -9 & 9751.434 & \multirow{2}{*}[2,6]{} \\
\hline & & IP 71/87 & IP160/87 & $\begin{array}{l}\text { IP } \\
34 / 85\end{array}$ & IP $15 / 67$ & IP $12 / 80$ & \\
\hline
\end{tabular}

Table 6: Commercial fuel values

\begin{tabular}{lllllll}
\hline \hline Fuel Type & $\mathrm{V}, \mathrm{cSt}$ & $\boldsymbol{\rho}, \mathrm{g} / \mathrm{cc}$ & $\mathrm{FP},{ }^{\circ} \mathrm{C}$ & $\mathrm{PP},{ }^{\circ} \mathrm{C}$ & $\mathrm{CV}, \mathrm{kcal} / \mathrm{kg}$ & Reference \\
\hline \hline Gasoline & 1.17 & 0.780 & 42 & - & 10157.74 & {$[43]$} \\
Diesel & $1.9-4.1$ & 0.807 & 52 & 6 & 10277.2 & {$[43]$}
\end{tabular}

Viscosity - V; Flash Point - FP; Ploud Point - PoP; Density - $\rho$; Calorific Value - CV

a@40 ${ }^{\circ} ;^{b} @ 25^{\circ} \mathrm{C} ;{ }^{c} @ 15^{\circ} \mathrm{C}$

of the BFK type magnetic rotary stirred pyrolysis reactor.The main objective of their study was to employ some form of renewable energy for the thermal chemical conversion process.A solar powered mobile unit, capable of converting waste plastics into fuel, which is comparable with conventional fuels has been developed by a team of students at IIT - Madras.The best part of this technology is that - being a mobile unit, can be driven directly to the place of waste collection and then process the waste.It is a total decentralised mechanism that needs no necessity to erect a processing plant and to transfer plastic wastes from the point of collection to the point of processing.The unit is capable of handling plastic bags, packaging material and other plastic items that are not normally collected for recycling by ragpickers can be used as raw materials. The team claims that waste plastic oil can be used as an alternative in generators, boilers, furnaces, pumps and diesel-powered vehicles [64].Guozhan Jiang et al. [65] performed a process simulation and a technoeconomic analysis of pyrolysis of mixed plastic 
Table 7: By-products of plastic pyrolysis.

\begin{tabular}{|l|l|l|l|l|l|l|}
\hline \hline $\begin{array}{l}\text { Waste plastic } \\
\text { Type }\end{array}$ & $\begin{array}{l}\text { Pyrolysis } \\
\text { temperature }\end{array}$ & $\begin{array}{l}\text { Crude oil } \\
\text { (wt. \%) }\end{array}$ & Residue (wt. \%) & Gas (wt. \%) & Wax (wt. \%) & References \\
\hline \hline PE & \multirow{2}{*}{500} & 93 & 0 & 7 & - & {$[57]$} \\
\cline { 2 - 7 } PP & 95 & 0 & 5 & - & {$[6]$} \\
\cline { 2 - 7 } & 300 & 69.82 & 1.34 & 28.84 & - & {$[58]$} \\
\hline Mixed & $370-420$ & 90 & 5 & 5 & - & {$[5]$} \\
HDPE & 500 & 44.32 & 1.29 & 25.4 & 28.99 & {$[6]$} \\
& 350 & 80.88 & 1.88 & 17.24 & - & {$[59]$} \\
\hline \multirow{4}{*}{ Mixed plastic } & 440 & 74 & 17 & 9 & - & {$[49]$} \\
& $300-400$ & $60-80$ & $7-10$ & $10-20$ & & {$[47,60]$} \\
& $400-500$ & $76.7 \pm 1.2$ & $16 \pm 1.2$ & $7.3 \pm 0.5$ & & {$[9]$} \\
\hline \multirow{2}{*}{ LDPE } & 500 & $\sim 55$ & $\sim 5$ & 240 & - & {$[61]$} \\
\hline PET & 800 & 73 & 23.5 & 30.4 & - & {$[45]$} \\
\hline \hline
\end{tabular}

waste (MPW) containing PVC that utilised molten solar salt as the heating medium. They observed that by adding calcium carbonate $\left(\mathrm{CaCO}_{3}\right)$ to the salt mixture, a practical way to remove chlorine from PVC was possible.Further, to melt the salt, the electricity generated from the non-condensable pyrolysis gas or concentrated solar power was used.A work on solar energy driven dielectric microwave oven was taken up by Debadyoti Ghosh et al. [66],the work involved use of sodium bentonite clay as a catalyst to endorse the conversion efficiency. HDPE and LDPE wastes were pyrolyzed in the temperature range of $450{ }^{\circ} \mathrm{C}$ to $500{ }^{\circ} \mathrm{C}$ under sub-atmospheric pressure inside the reactor chamber (vacuum chamber).Due to the vacuum pyrolysis, the harmful gases produced was considered negligible.

Pyrolysis-based biorefineries have a high potential for converting waste into energy and other useful goods, which might aid in the development of circular economies.Miandad et al. [67] worked on pyrolysis-based biorefineries that can convert plastic and biomass waste into energy and has the capability to convert them into valuable products. They used natural zeolite catalysts in a pilot scale reactor fabricated.Plastics such as PS, PE, PP, and PET in mixed ratio was used in the study.Work on co-pyrolysis of mahua seeds (MH) with PS and waste nitrile gloves (WNG) was investigated by RanjeetKumar Mishra and Kaustubha Mohanty [68].The PS and WNG wastes were mixed with $\mathrm{MH}$ in varying proportions. The results of blending showed that waste plastics at $20 \mathrm{wt}$.\% yielded a maximum liquid (44.18 \pm 1.2 wt. $\%$ and $45.89 \pm 1.4$ wt. $\%$ for $\mathrm{MH}+\mathrm{WNG}$ and $\mathrm{MH}+$ PS respectively), which was higher than the thermal pyrolysis of individual MH (39.26 \pm 1.2 wt.\%).Further, characterization of the obtained co-pyrolytic oil revealed that the oil could be used either directly or blended with the diesel after little upgradation.

Bimetallic catalysts are regarded as an important type of heterogeneous catalysts with exceptional catalytic characteristics compared to their separate metal components [69].Because of the existence of two metals, they can develop new and char- acteristic features.Ganjar Fadillah et al. [70] employed bimetallic catalysts in the pyrolysis of plastic waste to biofuel.Cia et al. [71] employed a carbon-based Fe-Ni bimetallic catalyst for rapid pyrolysis of plastic trash.In the procedure, a fixed bed reactor was employed, and the plastic-to-catalyst ratio was kept at 2:1 at a temperature of $500{ }^{\circ} \mathrm{C}$. The researchers indicated that the Fe-Ni bimetallic catalyst was critical in the oxygen reduction process.Because of the presence of an oxygen-containing functional group on the surface, the catalyst is also capable of avoiding corrosion on its surface.Zhou et al. [72] employed a bimetallic $\mathrm{Ni}-\mathrm{Fe} / \mathrm{ZrO}_{2}$ catalyst in their research involving polystyrene waste.The findings demonstrated that bimetallic catalysts increased catalytic activity in waste breakdown.

Also due to the pandemic and post-pandemic stage, the use and disposal of PPEs has increased and to effectively deal with the disposed PPEs which are mainly derived out of plastics, cold plasma technology in pyrolysis system has been adopted.This technology is effective in dealing with infectious medical plastic wastes, along with the high temperature of pyrolysis. The technique involves use of electrons to break the chemical bonds in plastics compared to the conventional pyrolysis.However, the process comes with a disadvantage that it needs an advanced cooling system [73, 74].

\section{Conclusion}

Pyrolysis process has the capacity to transform most plastic wastes into various valuable products such as liquid oil, wax, and char over other thermal treatment methods. Pyrolysis can be achieved via thermal or catalytic process; use of catalyst helps in attaining higher output of liquid oil for most polymers. The process's long-term viability is unquestionable, given that the amount of plastic waste at any point in the year in each nation is in the millions of tons. Waste management becomes more efficient using the pyrolysis process, which requires less landfill capacity, produces less pollution, and is also more cost- 
effective. Furthermore, because of the presence of the pyrolysis process for decomposing plastic into useful energy fuel, the reliance on non-renewable energy sources such as fossil fuels may be minimized, therefore alleviating the growth in energy demand. Among the various plastics, PE and PP plastics have the capacity to yield a greater amount of crude oil when subjected to pyrolysis at $500^{\circ} \mathrm{C}$ as compared to other plastics. Temperature below $500^{\circ} \mathrm{C}$ leads to production of more gases and other residues.

\section{Acknowledgement}

The authors would like to thank The Research Council Oman for fully funding the work described in this publication through the TRC Reg no: BFP/RGP/EBR/20/519. A special thanks is also extended to the University of Technology and Applied Sciences - Salalah (UTAS).

\section{References}

[1] W. A. Rasaq, M. Golonka, M. Scholz, and A. Bialowiec, "Opportunities and challenges of high-pressure fast pyrolysis of biomass: A review", Energies 14 (2021) 120, doi: 10.3390/en14175426.

[2] S. D. Anuar Sharuddin, F. Abnisa, W. M. A. Wan Daud, and M. K. Aroua, "A review on pyrolysis of plastic wastes", Energy Convers. Manag. 115 (2016) 308, doi: 10.1016/j.enconman.2016.02.037.

[3] F. Abnisa and W. M. A. Wan Daud, "A review on co-pyrolysis of biomass: An optional technique to obtain a high-grade pyrolysis oil", Energy Convers. Manag. 87 (2014) 71, doi: 10.1016/j.enconman.2014.07.007.

[4] S. D. A. Sharuddin, F. Abnisa, W. M. A. W. Daud, and M. K. Aroua, "Pyrolysis of plastic waste for liquid fuel production as prospective energy resource", IOP Conf. Ser. Mater. Sci. Eng. 334 (2018) 012001, doi: 10.1088/1757-899X/334/1/012001.

[5] S. Kumar and R. K. Singh, "Thermolysis of High-Density Polyethylene to Petroleum Products", J. Pet. Eng. 2013 (2013) 1, doi: $10.1155 / 2013 / 987568$.

[6] I. Ahmad et al., "Pyrolysis study of polypropylene and polyethylene into premium oil products", Int. J. Green Energy 12 (2015) 663 doi: 10.1080/15435075.2014.880146.

[7] J. Park, S. S., Seo, D. K., Lee, S. H., Yu, T. U., \& Hwang, "Study on pyrolysis characteristics of refuse plastic fuel using lab-scale tube furnace and thermogravimetric analysis reactor", J. Anal. Appl. Pyrolysis 97 (2012) 29 doi: https://doi.org/10.1016/j.jaap.2012.06.009.

[8] D. Oh, H. W. Lee, Y. M. Kim, and Y. K. Park, "Catalytic pyrolysis of polystyrene and polyethylene terephthalate over Al-MSU-F", Energy Procedia 144 (2018) 111, doi: 10.1016/j.egypro.2018.06.015.

[9] M. N. Islam and M. R. A. Beg, "Fixed Bed Pyrolysis of Waste Plastic for Alternative Fuel Production”, J. Energy Environ. 3 (2004) 69.

[10] Ö. and A. E. P. Cepeliogullar, "Utilization of Two Different Types of Plastic Wastes from Daily and Industrial Life.", J. Selcuk Univ. Nat. Appl. Sci. (2013) 694

[11] S. Erdogan, "Recycling of Waste Plastics into Pyrolytic Fuels and Their Use in IC Engines", in Intech, (2020) 137.

[12] A. Vijayakumar and J. Sebastian, "Pyrolysis process to produce fuel from different types of plastic - A review", IOP Conf. Ser. Mater. Sci. Eng. 396 (2018), 012062 doi: 10.1088/1757-899X/396/1/012062.

[13] S. Kumar and R. K. Singh, "Recovery Of Hydrocarbon Liquid from Waste High Density Polyethylene By Thermal Pyrolysis" 28 (2011) 659.

[14] W. P. Bagri R, "Catalytic pyrolysis of polyethylene", J. Anal. Appl. Pyrolysis. 63 (2002) 29

[15] N. R. Marcilla A, Beltrán M, "Thermal and catalytic pyrolysis of polyethylene over HZSM5 and HUSY zeolites in a batch reactor under dynamic conditions", Appl. Catal. B Environ. 86 (2009) 78.
[16] C. Hundertmark, T., Mayer, M., McNally, C., Simons, T. J., Witte, "Business Trends: How plastics waste recycling could transform the chemical industry", McKinsey \& Co. https://www.mckinsey.com/industries/chemicals/our-insights/howplastics-waste-recycling-could-transform-the-chemical-industry (accessed Oct. 16, 2021)

[17] Nordic Council, Hazardous substances in plastics. 2017.

[18] T. Makhmari, "Briefings from Oman Waste Management", Ithraa, Public Auth. Invest. Promot. Export Dev. (2016), [Online]. Available: https://ithraa.com/portals/0/IthraaPDF/Brochures/PDF/ithraa-briefingswaste-engAW.pdf.

[19] N. Singh, D. Hui, R. Singh, I. P. S. Ahuja, L. Feo, and F. Fraternali, "Recycling of plastic solid waste: A state of art review and future applications", Compos. Part B Eng. 115 (2017) 409 doi: 10.1016/j.compositesb.2016.09.013.

[20] A. Merrington, "Recycling of Plastics", in Applied Plastics Engineering Handbook, Elsevier Inc. (2011) 177.

[21] S. Kumar, A. K. Panda, and R. K. Singh, "A review on tertiary recycling of high-density polyethylene to fuel", Resources, Conservation and Recycling 55 (2011) 893, doi: 10.1016/j.resconrec.2011.05.005.

[22] M. E. Grigore, "Methods of recycling, properties and applications of recycled thermoplastic polymers", Recycling 2 (2017) 1, doi: 10.3390/recycling2040024.

[23] S. M. Al-Salem, P. Lettieri, and J. Baeyens, "Recycling and recovery routes of plastic solid waste (PSW): A review", Waste Management 29 (2009) 2625, doi: 10.1016/j.wasman.2009.06.004.

[24] A. Lee and M. S. Liew, "Tertiary recycling of plastics waste: an analysis of feedstock, chemical and biological degradation methods", J. Mater. Cycles Waste Manag. 23 (2021) 32, doi: 10.1007/s10163-020-01106-2.

[25] M. S. Qureshi et al., "Pyrolysis of plastic waste: Opportunities and challenges", J. Anal. Appl. Pyrolysis 152 (2020) 104804, doi: 10.1016/j.jaap.2020.104804.

[26] K. Ragaert, L. Delva, and K. Van Geem, "Mechanical and chemical recycling of solid plastic waste", Waste Manag. 69 (2017) 24, doi: 10.1016/J.WASMAN.2017.07.044.

[27] J. Lahtinen, "Thermolysis of plastic waste in bench-scale fluidized-bed reactor", January, 2019, [Online]. Available: https://www.theseus.fi/bitstream/handle/10024/160174/LahtinenJoona.pdf?sequence $=4$.

[28] M. S. Qureshi, A. Oasmaa, and C. Lindfords, "Thermolysis of plastic waste: Reactor comparison", Pyroliq 2019 Pyrolysis Liq. biomass wastes, (2019).

[29] "Fluid catalytic cracking is an important step in producing gasoline", Independent Statistics \& Analysis, U.S. Energy Information Administration, (2011). https://www.eia.gov/todayinenergy/detail.php?id=9150 (accessed Jun. 07, 2021).

[30] "Continuous Stirred Tank Reactors (CSTR) Flow Technology for Chemical and Biological Syntheses", METTLER TOLEDO. https://www.mt.com/hk/en/home/products/L1AutochemProducts/Chemical-Synthesis-and-Process-DevelopmentLab-Reactors/continuous-stirred-tank-reactors-cstr.html (accessed Jun. 09, 2021).

[31] P. H. S. Dinesh Mohan, Charles U. Pittman Jr., "Pyrolysis of Wood/Biomass for Bio-oil: A Critical Review", Energy Fuels 20 (2006) 848, doi: https://doi.org/10.1021/ef0502397.

[32] I. Miskolczi, N, Angyal, A, Bartha, L, and Valkai, "Fuels by pyrolysis of waste plastics from agricultural and packaging sectors in a pilot scale reactor", Fuel Process. Technol. 90 (2009) 1032, doi: https://doi.org/10.1016/j.fuproc.2009.04.019.

[33] S. Budsaereechai, A. J. Hunt, and Y. Ngernyen, "Catalytic pyrolysis of plastic waste for the production of liquid fuels for engines", RSC Advances 9 (2019) 5844, doi: 10.1039/c8ra10058f.

[34] T. D. Zeynep Obali, Naime Asli Sezgi, "Catalytic degradation of polypropylene over alumina loaded mesoporous catalysts", Chem. Eng. J. 207 (2012) 421, doi: https://doi.org/10.1016/j.cej.2012.06.146.

[35] M. Syamsiro et al., "Liquid and Gaseous Fuel from Waste Plastics by Sequential Pyrolysis and Catalytic Reforming Processes over Indonesian Natural Zeolite Catalysts", Waste Technol. 2 (2014) 44, doi: 10.12777/wastech.2.2.44-51.

[36] J. and K.-H. L. Walendziewski, Feedstock Recycling and Pyrolysis of Waste Plastics: Converting Waste Plastics into Diesel and Other Fuels. 
John Wiley \& Sons, Ltd.

[37] A. K. Panda, R. K. Singh, and D. K. Mishra, "Thermolysis of waste plastics to liquid fuel. A suitable method for plastic waste management and manufacture of value added products-A world prospective", Renew. Sustain. Energy Rev. 14 (2010) 233, doi: 10.1016/j.rser.2009.07.005.

[38] K. Murata, K. Sato, and Y. Sakata, "Effect of pressure on thermal degradation of polyethylene", J. Anal. Appl. Pyrolysis 71 (2004) 569, doi: 10.1016/j.jaap.2003.08.010.

[39] M. Syamsiro et al., "Fuel oil production from municipal plastic wastes in sequential pyrolysis and catalytic reforming reactors", Energy Procedia 47 (2014) 180, doi: 10.1016/j.egypro.2014.01.212.

[40] J. A. Onwudili, N. Insura, and P. T. Williams, "Composition of products from the pyrolysis of polyethylene and polystyrene in a closed batch reactor: Effects of temperature and residence time", J. Anal. Appl. Pyrolysis 86 (2009) 293, doi: 10.1016/j.jaap.2009.07.008.

[41] "Pour point", Energy Insights by McKinsey. https://www.mckinseyenergyinsights.com/resources/refinery-referencedesk/pour-point/ (accessed Jul. 26, 2021).

[42] J. Durkee, "Health and safety hazards associated with cleaning agents", Manag. Ind. Clean. Technol. Process. (2006) 99, doi: 10.1016/B978008044888-6/50017-X.

[43] M. Z. H. Khan, M. Sultana, M. R. Al-Mamun, and M. R. Hasan, "Pyrolytic Waste Plastic Oil and Its Diesel Blend: Fuel Characterization", J. Environ. Public Health 2016 (2016), doi: 10.1155/2016/7869080.

[44] M. Syamsiro et al., "Fuel oil production from municipal plastic wastes in sequential pyrolysis and catalytic reforming reactors", Energy Procedia 47 (2014) 180 , doi: 10.1016/j.egypro.2014.01.212.

[45] A. Jayswal, A. Kumar, P. Pradhananga, S. Rohit, and H. Bahadur, "Design, Fabrication and Testing of Waste Plastic Pyrolysis Plant", Proc. IOE Grad. Conf. 5 (2017) 275, doi: 10.13140/RG.2.2.33682.15044.

[46] A. S. Nugroho, Rahmad, M. Chamim, and F. N. Hidayah, "Plastic waste as an alternative energy", AIP Conf. Proc. 1977 2018, doi: 10.1063/1.5043022.

[47] Y. Shukla, H. Singh, S. Sonkar, and D. Kumar, "Design Of Viable Machine To Convert Waste Plastic Into Mixed Oil For Domestic Purpose a Yasha Shukla , b Hemant Singh * , b Shiwangi Sonkar and b Deepak Kumar" 12 (2016) 9.

[48] P. Harshal and L. Shailendra, "Waste plastic Pyrolysis oil Alternative Fuel for CI Engine - A Review”, Res. J. Eng. Sci. 2 (2013) 26.

[49] A. Zadgaonkar, "Conversion of Waste Plastic into Liquid Hydrocarbons / Energy", [Online]. Available: http://www.frantechasia.com/Downloads/Eco Friendly Plastic Fuel.pdf.

[50] R. T. Karad and S. Havalammanavar, "Waste plastic to fuel-Petrol, Diesel , Kerosene", Int. J. Eng. Dev. Res. 5 (2017) 641.

[51] S. H. Jung, M. H. Cho, B. S. Kang, and J. S. Kim, "Pyrolysis of a fraction of waste polypropylene and polyethylene for the recovery of BTX aromatics using a fluidized bed reactor", Fuel Process. Technol. 91 (2010) 277, doi: 10.1016/J.FUPROC.2009.10.009.

[52] M. A. Martín-Lara, A. Piñar, A. Ligero, G. Blázquez, and M. Calero, "Characterization and use of char produced from pyrolysis of postconsumer mixed plastic waste", Water (Switzerland) 13 (2021) 1, doi: 10.3390/w13091188.

[53] S. Vivekanandhan, "Biochar Supercapacitors: Recent Developments in the Materials and Methods", in Green and Sustainable Advanced Materials: Applications, II, C. M. H. Shakeel Ahmed, Ed. Scrivener Publishing LLC, 2018

[54] D. Spanu, G. Binda, C. Dossi, and D. Monticelli, "Biochar as an alternative sustainable platform for sensing applications: A review", Microchem. J. 159 (2020) 105506, doi: 10.1016/J.MICROC.2020.105506.

[55] S. Pandey et al., "Graphene nanosheets derived from plastic waste for the application of DSSCs and supercapacitors", Sci. Rep. 11 (2021) 3916, doi: 10.1038/s41598-021-83483-8.

[56] P. Basu, Biomass Gasification and Pyrolysis Practical Design. Academic
Press, 2010.

[57] P. T. Williams and E. Slaney, "Analysis of products from the pyrolysis and liquefaction of single plastics and waste plastic mixtures", Resour. Conserv. Recycl. 51 (2007) 754, doi: 10.1016/J.RESCONREC.2006.12.002.

[58] M. Sarker, "Converting waste plastic to hydrocarbon fuel materials", Energy Eng. J. Assoc. Energy Eng. 108 (2011) 35, doi: 10.1080/01998595.2011.10389018.

[59] B. K. Sharma, B. R. Moser, K. E. Vermillion, K. M. Doll, and N. Rajagopalan, "Production, characterization and fuel properties of alternative diesel fuel from pyrolysis of waste plastic grocery bags", Fuel Process. Technol. 122 (2014) 79, doi: 10.1016/J.FUPROC.2014.01.019.

[60] N. Insura, J. Onwudili, P. T. Williams, and E. Engineering, "Converting Waste plastic To Gasoline-like Fuel at low temperature", (2001).

[61] S. M. Alston, A. D. Clark, J. C. Arnold, and B. K. Stein, "Environmental impact of pyrolysis of mixed WEEE plastics part 1: Experimental pyrolysis data", Environ. Sci. Technol. 45 (2011) 9380, doi: $10.1021 / \mathrm{es} 201664 \mathrm{~h}$

[62] A. T. Habtewold, D. A. Ambie, and W. B. Eremed, "Solar assisted pyrolysis system for High-Density polyethylene plastic waste to fuel conversion", AIMS Energy 8 (2020) 455, doi: 10.3934/energy.2020.3.455.

[63] C. Ghenai, K. Alamara, and A. Inayat, "Solar Assisted Pyrolysis of Plastic Waste: Pyrolysis oil Characterization and Grid-Tied Solar PV Power System Design", Energy Procedia 159 (2019) 123, doi: 10.1016/J.EGYPRO.2018.12.029.

[64] "Solar-powered unit turns plastic waste into fuel oil", The New Indian Express, 2018.

[65] G. A. L. Guozhan Jiang, Jiawei Wang, Sultan.M. Al-Salem, "Molten Solar Salt Pyrolysis of Mixed Plastic Waste: Process Simulation and Technoeconomic Evaluation”, Energy Fuels 34 (2020) 7397, doi: https://doi.org/10.1021/acs.energyfuels.0c01052.

[66] D. Ghosh, S. K. Bandyopadhyay, and G. S. Taki, "Green Energy Harvesting from Waste Plastic Materials by Solar Driven Microwave Pyrolysis", 2020 4th Int. Conf. Electron. Mater. Eng. Nano-Technology, IEMENTech (2020), doi: 10.1109/IEMENTech51367.2020.9270122.

[67] R. Miandad et al., "Catalytic pyrolysis of plastic waste: Moving toward pyrolysis based biorefineries", Front. Energy Res. 7 (2019) 1, doi: 10.3389/fenrg.2019.00027.

[68] R. Kumar Mishra and K. Mohanty, "Co-pyrolysis of waste biomass and waste plastics (polystyrene and waste nitrile gloves) into renewable fuel and value-added chemicals", Carbon Resour. Convers. 3 (2020) 145, doi: 10.1016/j.crcon.2020.11.001.

[69] A. Alshammari, V. N. Kalevaru, and A. Martin, "Bimetallic Catalysts Containing Gold and Palladium for Environmentally Important Reactions", 2016, doi: 10.3390/catal6070097.

[70] G. Fadillah, I. Fatimah, I. Sahroni, and M. M. Musawwa, "Recent Progress in Low-Cost Catalysts for Pyrolysis of Plastic", 2021.

[71] N. Cai et al., "Bimetallic carbon nanotube encapsulated $\mathrm{Fe}-\mathrm{Ni}$ catalysts from fast pyrolysis of waste plastics and their oxygen reduction properties", Waste Manag. 109 (2020) 119, doi: 10.1016/j.wasman.2020.05.003.

[72] H. Zhou, J. M. Saad, Q. Li, and Y. Xu, "Steam reforming of polystyrene at a low temperature for high $\mathrm{H} 2 / \mathrm{CO}$ gas with bimetallic Ni-Fe/ZrO2 catalyst", Waste Manag. 104 (2020) 42, doi: 10.1016/J.WASMAN.2020.01.017.

[73] L. Yao, J. King, D. Wu, S. S. C. Chuang, and Z. Peng, "Non-thermal plasma-assisted hydrogenolysis of polyethylene to light hydrocarbons", Catal. Commun. 150 (2021) 106274, doi: 10.1016/J.CATCOM.2020.106274

[74] M. M. Harussani, S. M. Sapuan, U. Rashid, A. Khalina, and R. A. Ilyas, "Pyrolysis of polypropylene plastic waste into carbonaceous char: Priority of plastic waste management amidst COVID-19 pandemic", Sci. Total Environ. 803 (2022) 149911, doi: 10.1016/j.scitotenv.2021.149911. 